\title{
Love, Life and Politics: Comparing Lutheran and Orthodox Political Theologies
}

\author{
Aristotle Papanikolaou
}

In this essay, I want to engage Luther's political theology by engaging Michael Laffin's recent book, The Promise of Martin Luther's Political Theology. I am fully aware of the debates around Luther's political theology and realize that Laffin's is only one interpretation, but it is a very nuanced interpretation that offers compelling arguments. I then want to illustrate affinities between Laffin's interpretation of Luther and my own Orthodox political theology based on the realism of divinehuman communion, or theosis. I then want to end by relating this comparison to what is arguably one of the most pressing questions of Christian political theology the Christian's relation to political liberalism.

Keywords: political theology, Orthodox theology, Zizioulas, ecclesiology, communion, Luther, Russian Orthodoxy, human rights, liberalism.

Laffin begins by critiquing the caricatures of Luther's political theology, primarily those offered by John Milbank. Milbank's Luther places him in the nominalist tradition, which because of its univocal understanding of being, ultimately created the conditions for a desacramentalization of created reality. This nominalist understanding of the God-world relation is the context within which Luther developed his understanding of justification by faith alone, which ultimately reduced the sacred to the individual heart of the believer. This singular declaration ultimately laid the groundwork for political liberalism, which Milbank sees as antithetical to a Christian ontology of participation. Ultimately Milbank blames liberalism's excessive individualism and secular immanentism on Luther; not that such a political arrangement or philosophy was ever Luther's intent, but rather that it is the extension of the nominalist logic that ultimately grounds Luther's theology. For Milbank, Luther's political theology of two kingdoms ultimately sidelined religion from the public sphere, leading not simply to Church - State separation, but the privatization and marginalization of religion from the political space. Political liberalism is ultimately bad theology, according to Milbank, and Luther, in the end, contributed to this bad theology.

\footnotetext{
* Aristotle Papanikolaou, Professor of Theology, Fordham University, Archbishop Demetrios Chair in Orthodox Theology and Culture, Co-founding Director, Orthodox Christian Studies Center. Address: Orthodox Christian Studies Center Theology, 924, 113 W. 60th St., New York, NY 10023, e-mail: papanikolaou@fordham.edu
} 
Laffin refutes this account of Luther, accusing Milbank, not surprisingly, of an un-nuanced understanding of Luther's theology. Like most of Luther's interpreters, Laffin sees Milbank falling into the trap of conflating Luther's two kingdoms with his two regiments, ultimately identifying the temporal regiment with the kingdom of Satan. It is a common mistake, in no small part due to Luther's Lutheran interpreters, especially those of the late nineteenth and early twentieth centuries.

For a fuller picture, Laffin argues that there are several "twos" in Luther: two kingdoms, two ecclesiae, and two regiments, in addition to one "three", which are the three institutes. Most interpret Luther as having a negative view of politics because few ever take into account his three institutes, which are the ecclesia, the politeia and the oikonomia. Getting back to Laffin, the relation between these pieces of Luther's political theology ultimately depend on a proper understanding of the relation of justification and sanctification in Luther's theology. In countering the typical picture of Luther's political theology, Laffin begins by affirming the inseparability of justification and sanctification. He affirms the recent Finnish school research on Luther, without using the language of theosis, or appealing to ontological language. Otherwise, Laffin agrees with the Finnish school that justification is union with Christ, and in that sense, is a union with all that Christ has accomplished, offers and is. Rather than ontological language, Laffin prefers to use the language of speech and communication to understand more generally the relation between God and creation, and the metaphor of marital union to understand the union of those justified in faith with Christ. Justification by faith does not simply give a correct understanding of God and self, but is actually transformative; it entails an affective dimension. It is, thus, not the case that justification occurs as an event and sanctification is a process; both occur simultaneously and effect a transformation that frees the Christian to love the neighbor. The Christian must still battle the flesh in Christian living, but this battle is not to attain sanctification but to form the affections in such a way as to return the Christian to what has already been given-union in Christ. The distinction-but not separation-between justification and sanctification can be properly understood on the basis of Luther's distinction between grace and gift. Grace refers to salvation, which occurs by our being justified; there is nothing we can do to earn salvation-it is entirely a graced event in faith. Gift, however, is, according to Laffin, "the indwelling presence of Christ, which works to gradually form the believer into the form of Christ. While grace is total and complete, the gift is partial and gradual." (124)

This understanding of justification and sanctification forms the basis for a more positive account of the political in Luther's theology, and not 
simply the negative account of the political use of law and government for restraining sin. To understand this positive understanding of politics according to the grammar of Luther's theology, we must first understand that Luther's two kingdoms do not map onto the distinction between Church and state, but express more the battle between good and evil. This does not mean that Luther affirms a kind of Gnostic dualism, since ultimately even Satan's kingdom could not exist if God did not allow it. Within the worldly realm, Satan's kingdom is ultimately perpetuated not necessarily by temporal government, but by an ecclesia that is constituted by turning away from the Word of God addressed to creation; and insofar as the institute of ecclesia is intertwined with those of politeia and oikonomia, such a turning away affects these other two institutes in such a way as to maintain Satan's kingdom.

God's kingdom is ultimately one rule of God that is manifested in a twofold manner, or two regiments, and over-and-against the kingdom (or ecclesia) of the devil. Christian living in the world is constituted at creation not simply by the politeia, that is in relation to temporal governance or the law, but also constituted by ecclesia and oikonomia. Laffin indicates that insofar as the law was given prior to the Fall, the law has a positive use for forming the affections, and not simply a negative use for restraining sin. The institutes of ecclesia, politeia and oikonomia form a constitutive part of creation of the one Word of God, and in that sense, are tethered to the promises of God and form the space for the formation of life in relation to God. In the language of justification and sanctification, since they are constitutive of God's creation, they are the arena in which the justified Christian freely turns to love neighbor, and thus, to form the affections so as to return to the sanctification already given in union with Christ, and in so doing, give Christ to the neighbor. But if the institutes are such a space, then the bonds of trust the Christian learns within the Eucharist are then the basis for the Christian to participate in the search for the common good, as the Christian freely loves the neighbor through living within the ecclesia, the politeia and the oikonomia.

In this configuration, the human being is never not in some way responding to the Word of God, either positively or negatively. God's rule is one, God is everywhere present and always addressing God's creation. The justified Christian can affect positively the politeia and the oikonomia through the ecclesia, and in so doing both affirm the good of politics, while maintaining a critical distance from politics. The Christian can also affirm that the non-Christian can do good and even manifest some of the marks of holiness, even if the non-Christian is not saved, since such salvation occurs only through justification and is a graced event initiated only by God 
and experienced in faith. Thus, Luther's political theology does not promote quietism and the maintenance of the status quo, since the justified Christian is free to love the neighbor. In the form of the politeia and oikonomia, that love of neighbor entails forming bonds of trust with others in the search for the common good.

I realize that Laffin's interpretation is one among many, and I am not equipped to enter into the debate on the correct interpretation of Luther. I am drawn to Laffin's interpretation because even though there are significant differences theologically, in terms of political theology, we end with very similar conclusions, especially in seeing the inter-relation between God, incarnation, theological anthropology and politics.

Since Laffin began with dismantling caricatures of Luther's political theology, let me begin by dismantling some of the caricatures of Orthodox political theology, some of which are perpetuated by the Orthodox themselves, similar to how caricatures of Lutheran political theology resulted from Lutheran theologians. First, Orthodox political theology is for the most part, even today, framed in relation to the well-known concept of symphonia. Symphonia has often been interpreted as a kind of top-down structure, in which the authority of God is divided into two spheres, that concerning spiritual matters related to the Church, and that concerning worldly matters related to the emperor. Some have even thought that symphonia leads to a kind of caesaropapism, in which the kingly and priestly authority is concentrated in the emperor. Historically, there have been many forms of symphonia, from the Byzantine emperor, to Tsarist Russia, to the nationstate in which Orthodoxy is an established religion, to the situation we see now in post-communist countries, especially Russia. The well-known Orthodox ethicist, Stanley Harakas, even argued that the situation in the United States, where Orthodox comprise not even 1\% of the population, can be interpreted as a kind of symphonia. ${ }^{1}$

It is easy to misinterpret symphonia as a kind of top-down symbolization of authority from God to the emperor and the church; however, Eusebius of Ceasarea, who can be credited for giving the first theological language for symphonia, saw it as the result of the evolutionary expansion of the Logos in creation. ${ }^{2}$ In that sense, he saw it as a kind of progressive theosis of creation that extended to structures of the Roman Empire. The persecution of Christians prior to the second half of the $4^{\text {th }}$ century often makes us forget

\footnotetext{
Stanley Harakas, "Orthodox Church-State Theory and American Democracy”, in: Greek Orthodox Theological Review 21 (4/1976), p. 399-421.

2 See Aristotle Papanikolaou, The Mystical as Political: Democracy and Non-Radical Orthodoxy, Notre Dame, University of Notre Dame Press 2012, p. 13-54.
} 
that Christians eventually became very proud Romans. They did not argue for a diametrical opposition between an imagined Christian state and the Roman imperial structures, but argued that all that was needed was for the Empire to worship the true God, revealed in Christ. Once this occurred and infiltrated the imperial structures, such structures could then be properly oriented in such a way as to facilitate the extension of the Logos in creation, as God intended. In this sense, the Christian Roman Empire was structured so as to facilitate the worship of God, and such intentionality was guided by the dual authorities of emperor and clergy, even if the relation between the two was constantly being contested.

In saying all this, I am not defending symphonia, so much as clarifying what I think was the theological architecture of Christian Roman political theology. I do also want to argue that theosis should still be the theological basis for thinking the political, but that it does not, as Eusebius imagined, lead to a political space in which the legal frameworks are structured around theological principles. In fact, quite the opposite, as I argue that a theological affirmation of the human being created for theosis leads to political structures that maximize pluralism, and, in that sense, work against legal structures framed according to a common theological perspective.

To restate briefly my argument given in my book, The Mystical as Political, if theosis is to become like God in union with God, and if God is love, then theosis entails loving as God loves in the world, including the stranger and the enemy. The Christian ascetical tradition understood well that humans do not love God with all heart, mind and soul, and that such love is experienced through ascesis. Ascesis should not be immediately imagined as negative, as it could entail practices of truth-telling, attentive listening, moderation in relation to resources, and other practices that are not about self-flagellation. The goal ultimately is to gain self-knowledge on the sources that block experiencing God's love—such as anger, fear and hatred, and a doing of practices that make one more available to experiencing this love, which then would constitute one as more loving toward the neighbor, including the enemy and stranger.

I have further argued that politics is a kind of ascesis. As I state in The Mystical as Political:

If the Christian calling is to learn how to love, then an ascetics of divine-human communion cannot be confined either to the monastery or to the church - the whole world is the field in which this ascetics must be played out. And if this learning how to love goes beyond family or other Christians, and includes the neigh- 
bor, who may also be the stranger, then politics cannot be irrelevant to an ascetics of divine-human communion. In fact, insofar as politics can be construed as an engagement with the neighbor/ stranger, then politics must be considered as one of the many practices within an ascetics of divine-human communion. The political community is not the antithesis to the desert but one of the many deserts in which the Christian must combat the demons that attempt to block the learning of love. In no other field is the temptation to demonize the neighbor more compelling or more seemingly justifiable than in the field of politics; in no other space than in the political, then, is the Christian more challenged to fulfill the commandment to love. ${ }^{3}$

Similar to Laffin's interpretation of Luther, I argue that the Christian's movement is from the Eucharist to the non-Eucharistic space of the political. If the Christian were to encounter this space as one in which she engages in the Eucharistic ascesis of learning to love, especially the one who does not share her belief, or is even out to destroy this belief, then the Christian would work toward legal and civic structures that ultimately are based on what I would call a liberal minimalism - which entail principles of freedom, equality and pluralism. This does not mean that the Christian would accept what has been identified as a liberal anthropology of the autonomous self, excessive individualism and infinitely incited consumerism. In fact, the Christian would also work toward a common good, constituted through a pluralism of voices, that would mitigate against excessive individualism and consumerism, toward a relational self whose flourishing and irreducible uniqueness is constituted through an acknowledged dependence on the other. I argue against those who claim that political liberalism and a politics of the common good are mutually exclusive. In the end, a politics of theosis would affirm what I would call a Christian secularism, which does not entail an evacuation of religious voices from political life, but would entail a negation of a common theological perspective as a frame for legal and civic structures, and in order to secure a pluralism that affirms freedom and equality.

At this point, I would like to highlight what Laffin and I have in common. First, both our approaches attempt a deep read of the tradition in order to cut through caricatures. Laffin is attempting to dismantle a perception of Lutheran political theology as quietistic; and, there are perceptions of Orthodox political theology as also quietistic in the sense that since Orthodoxy seemingly accommodated itself to the state, then it continues to do so no matter what state structure exists. Both Laffin and I are attempting to

$3 \quad$ Ibidem, p. 4. 
reorient political theology from abstract concepts, such as two governments or symphonia, toward a political theology based on Christian living that expresses itself as love toward the neighbor. Both of us make love central to political theology. This Christian living is based on an anthropology that is informed by soteriology, and in that sense, is based on God's revelation in Christ. We are also both attempting to maintain the integrity of a nonecclesial space, with which the ecclesia engages while maintaining a critical distance. I wholeheartedly agree with Laffin when he critiques Milbank for absorbing the political into the ecclesia and not maintaining the difference between the two.

Where we differ, however, is significant and brings us to one of the most pressing questions of political theology today. Whereas Laffin is attempting to rescue Luther from charges of laying the groundwork for political liberalism, I am trying to argue for an Orthodox affirmation of the principles of political liberalism. Whereas Laffin is trying to refute Milbank's critique of Luther, I am trying to rescue theosis from Milbank's political theology. Laffin is trying to put forward a Lutheran political theology that is not quietistic, that is also not to be identified with modern political liberalism, but, instead, maintains a relationship of critical engagement between the ecclesia and the politeia. While rescuing Luther from Milbank's charges, Laffin appears to accept Milbank's critique of modern political liberalism. In so doing, it is very unclear in Laffin's account what the politeia should look like. And without a more positive account of what the politeia should look like, then it is hard to escape the charge of quietism in relation to political structures. Also, without a clearer sense of what the politeia should look like, of what the Christian should be working toward in the politeia when emerging from the ecclesia, he is in danger of eliding the ecclesia and the politeia, since it is not enough simply to claim that the politeia is the realm of the co-mixing of the saved and the unsaved.

There has to be a clearer sense of how the saved and unsaved should relate to each other for the politeia to have its own integrity. I have argued and continue to argue that Christian living that expresses itself as a learningto-love-neighbor would ultimately work toward structures framed by minimal liberal principles, and even more strongly — that such a politeia iconizes the Eucharistic communion to a greater degree than other imaginable political arrangements. Perhaps it is the Orthodox notion of icon, unavailable within Lutheran theology more generally, that allows me to make such a claim in a way that is not possible for Laffin. I also think, however, that we may differ on the dynamics of love. Laffin wants an account of love that springs from faith-as-trust, which exists in justification; I would affirm that 
trust is a necessary but not sufficient condition for love, which can grow or deepen through practices. My argument, in short, is that the practices of love are those that would ultimately shape a politeia - the non-ecclesial spacearound the liberal principles of freedom, equality and pluralism.

I would like to end with a case study that, for me, highlights the need for a more explicit affirmation of what the politeia should look like. Recently the Russian Orthodox Church issued a document on human rights, that ultimately attempts to advance what may be a called a particularistic approach to human rights. ${ }^{4}$ Having clearly in mind the extension of human rights to the LGBT community in Western European countries and the US, the ROC is arguing for a notion of human rights that is linked with morality. The gist of the argument is that although each human being has a God-given dignity, rights should not be extended in such a way that conflict with morality, since the latter is what confers dignified life. It comes as no surprise, then, that the ROC would seek to deny rights that have "legislative and public support given to various vices, such as sexual lechery and perversions," but also to "the worship of profit and violence ... abortion, euthanasia, use of human embryos in medicine, experiments changing a person's nature and the like" (III.3). A little more unusual is the ROC's claim that "human rights should not contradict love for one's homeland and neighbours," (III.4), which the ROC justifies by claiming that the "Orthodox tradition traces patriotism back to the words of Christ the Saviour Himself: "Greater love has no one than this, that he lay down his life for his friends' (Jn. 15:13)." The ROC amplifies by stating that "One's human rights cannot be set against the values and interests of one's homeland, community and family. The exercise of human rights should not be used to justify any encroachment on religious holy symbols things (sic.), cultural values and the identity of a nation" (IV.1). Such rights are excluded because, for the ROC, "In Orthodoxy, there is an immutable conviction that in ordering its life a society should take into account not only human interests and wishes but also the divine truth, the eternal moral law given by the Lord and working in the world no matter whether the will of particular people or people's communities agree with it or not" (III.2).

The severing of rights from morality, according to the ROC, is a socalled "Western" colonial construct, and the ROC is arguing for an affirmation of human rights language but interpreted within the particularistic morality of a given nation or culture. Such a document would not be big news except for the fact that since 2012, the ROC is actively working with the Russian government to advance this particularistic approach to human

4 https://mospat.ru/en/documents/dignity-freedom-rights/ 
rights in the UN Human Rights Council, and they are doing so through a global alliance centred on the promotion of traditional values. ${ }^{5}$ The Russians have succeeded in forging a new East-West geopolitical divide but this time the dividing line is defined not in terms of communism versus capitalism, but in terms of traditional values versus so-called godless liberalism.

It probably comes as no surprise that I think what the Russian Orthodox Church is proposing is based on bad theology that is designed to advance Russian national interests. In the end, the Russians elide the political and the ecclesial, by appropriating a political concept, like human rights, for advancing a so-called 'dignified life' that is itself an ecclesial reality. Human rights structure relations analogous to but not identical with ecclesial relations and in so doing must allow for practices unthinkable within the Church - such as disbelief in God. In fact, a theological interpretation of human rights would see them as structuring relations among Christians and non-Christians such that the irreducible uniqueness of the human is realized as much as is possible within the politeia, while realizing that the fullness of personhood is a Eucharistic reality. I would like to conclude with a question to this case study: what does a Lutheran political theology along the lines of Laffin's interpretation call for in response to the ROC particularistic interpretation of human rights? And what would this imply for the shape of the politeia demanded by this Lutheran political theology?

Vebjørn N. Horsfjord, "Negotiating Traditional Values: The Russian Orthodox Church at the United Nations Human Rights Council (UNHRC)", in: Anne Stensvold (ed.), Religion, State and the United Nations, London, Routledge 2017, p. 62-78; Kristian Stoeckl, "The Russian Orthodox Church as moral norm entrepreneur", in: Religion, State, Society 44 (2/2016), p. 132-151. 